\title{
Discovery of Marine Natural Products as Promising Antibiotics against Pseudomonas aeruginosa
}

\author{
Haoran Li ${ }^{1,2,+}$, Mireguli Maimaitiming 1,2,+, Yue Zhou ${ }^{1,2}$, Huaxuan Li ${ }^{1,2}$, Pingyuan Wang ${ }^{1,2}$, Yang Liu ${ }^{3}$, \\ Till F. Schäberle ${ }^{3,4,5}\left(\mathbb{D}\right.$, Zhiqing Liu ${ }^{1,2, *}$ (D) and Chang-Yun Wang ${ }^{1,2, *}$ \\ 1 Institute of Evolution \& Marine Biodiversity, School of Medicine and Pharmacy, \\ College of Food Science and Engineering, Ocean University of China, Qingdao 266003, China; \\ 17853148949@163.com (H.L.); 17599791586@163.com (M.M.); ouc_zhouyue@163.com (Y.Z.); \\ huaxuan_lee@163.com (H.L.); wangpingyuan@ouc.edu.cn (P.W.) \\ 2 Laboratory for Marine Drugs and Bioproducts, Qingdao National Laboratory for Marine Science and \\ Technology, Qingdao 266237, China \\ 3 Institute for Insect Biotechnology, Justus-Liebig-University Giessen, Ohlebergsweg 12, \\ 35392 Giessen, Germany; liu.yang@agrar.uni-giessen.de (Y.L.); till.f.schaeberle@agrar.uni-giessen.de (T.F.S.) \\ 4 Branch for Bioresources, Fraunhofer Institute for Molecular Biology and Applied Ecology (IME), \\ 35392 Giessen, Germany \\ 5 Partner Site Giessen-Marburg-Langen, German Center for Infection Research (DZIF), \\ 35392 Giessen, Germany \\ * Correspondence: liuzhiqing@ouc.edu.cn (Z.L.); changyun@ouc.edu.cn (C.-Y.W.) \\ + These authors contributed equally to this work.
}

Citation: Li, H.; Maimaitiming, M.; Zhou, Y.; Li, H.; Wang, P.; Liu, Y.; Schäberle, T.F.; Liu, Z.; Wang, C.-Y. Discovery of Marine Natural Products as Promising Antibiotics against Pseudomonas aeruginosa. Mar. Drugs 2022, 20, 192. https:// doi.org/10.3390/md20030192

Academic Editor: Bill J. Baker

Received: 11 February 2022

Accepted: 3 March 2022

Published: 4 March 2022

Publisher's Note: MDPI stays neutral with regard to jurisdictional claims in published maps and institutional affiliations.

Copyright: (c) 2022 by the authors. Licensee MDPI, Basel, Switzerland. This article is an open access article distributed under the terms and conditions of the Creative Commons Attribution (CC BY) license (https:// creativecommons.org/licenses/by/ $4.0 /)$.

\begin{abstract}
Pseudomonas aeruginosa, one of the most intractable Gram-negative bacteria, has become a public health threat due to its outer polysaccharide layer, efflux transporter system, and high level of biofilm formation, all of which contribute to multi-drug resistance. Even though it is a pathogen of the highest concern, the status of the antibiotic development pipeline is unsatisfactory. In this review, we summarize marine natural products (MNPs) isolated from marine plants, animals, and microorganisms which possess unique structures and promising antibiotic activities against P. aeruginosa. In the last decade, nearly 80 such MNPs, ranging from polyketides to alkaloids, peptides, and terpenoids, have been discovered. Representative compounds exhibited impressive in vitro anti-P. aeruginosa activities with MIC values in the single-digit nanomolar range and in vivo efficacy in infectious mouse models. For some of the compounds, the preliminary structure-activity-relationship (SAR) and anti-bacterial mechanisms of selected compounds were introduced. Compounds that can disrupt biofilm formation or membrane integrity displayed potent inhibition of multi-resistant clinical $P$. aeruginosa isolates and could be considered as lead compounds for future development. Challenges on how to translate hits into useful candidates for clinical development are also proposed and discussed.
\end{abstract}

Keywords: Pseudomonas aeruginosa; anti-microbial activity; marine natural product; polyketide; peptide; biofilm

\section{Introduction}

Infectious diseases have always threatened human health, survival, and development. Antibiotics represent the first solution to combat bacterial infections. Generally speaking, antibiotics take effects through disrupting cell wall synthesis, cell membrane integrity, protein synthesis (e.g., 30S ribosome and 50S ribosome inhibitors), nucleic acid synthesis (e.g., DNA gyrase inhibitors and RNA synthesis inhibitors), or folate synthesis (Figure 1) [1]. However, accompanying their use, drug-resistant bacteria have emerged. Bacteria survive under antibiotic stress via molecular mechanisms including expression of efflux pumps, altered outer membrane $(\mathrm{OM})$ permeability, generation of inactivating enzymes, and target modification [2]. Thereby, the difficulties of curing microbial infectious diseases increased 
again, compelling people to find new drugs and methods. The common multidrug resistant bacteria in clinic include methicillin resistant Staphylococcus aureus (MRSA), vancomycin resistant Enterococcus (VRE), carbapenem resistant Enterobacteriaceae, and multidrug resistant Pseudomonas aeruginosa (MDR-PA) [3]. It should be noted that carbapenem-resistant $P$. aeruginosa was the top category of the "priority pathogens" list published by the World Health Organization (WHO) in February 2017 [4].

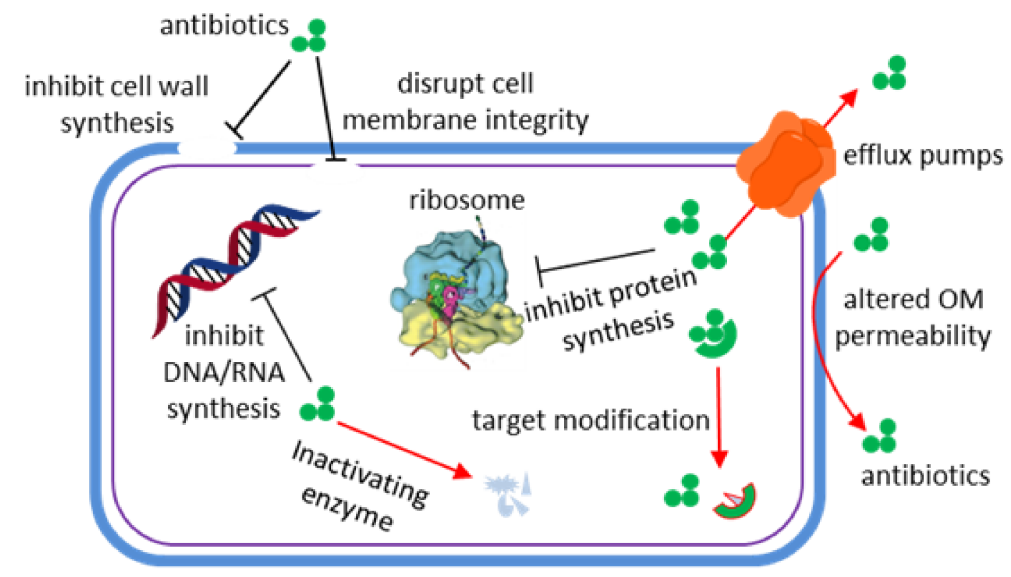

Figure 1. Antimicrobial (black lines) and resistance mechanisms (red arrows) of antibiotics [1].

As an opportunistic pathogen occurring widely in the environment (as well as the human gut), P. aeruginosa causes infections in blood, lung, urinary tract, kidney, and other body parts of immunocompromised patients (especially after surgery) [5,6]. As with other Gram-negative pathogens, $P$. aeruginosa possesses an outer polysaccharide layer, multidrug efflux transporters, and shows a high level of biofilm formation, together leading to a high probability of antibiotic-resistance [7-9]. Even worse, the outer membrane of $P$. aeruginosa is much less permeable (e.g., the porin OprF has a two orders of magnitude lower permeability than OmpF of E. coli) and its efflux pumps are more efficient in expelling antibiotics [10]. In addition, gene mutations in $P$. aeruginosa result in enhanced production of antibiotic-inactivating enzymes, overexpression of efflux pumps, and decreased expression of porins [11-14]. Furthermore, the occurrence of bacterial persister cells give rise to persistent infections and poor prognosis in cystic fibrosis (CF) patients [15]. Thus, P. aeruginosa has become a devastating public health threat due to its intrinsic, acquired, and adaptive resistance factors.

Although there are some antibiotics used as monotherapy or combination therapy in clinic to treat $P$. aeruginosa infections, including aminoglycosides (e.g., tobramycin), carbapenems (e.g., imipenem), cephalosporins (e.g., ceftazidime), fluoroquinolones (e.g., ciprofloxacin), Fosfomycin and polymyxins (e.g., colistin), the discovery of new antimicrobial compounds with new modes of action and the potential to overcome resistance is still demanded. In contrast to the rise of multi-drug resistant bacteria, little progress has been made in the introduction of novel antibiotics into the market in the last 20 years [16]. The most recently approved antibacterial drug in 2019, cefiderocol, is a siderophore-conjugated $\beta$-lactam antibiotic [17]. There are several anti-P. aeruginosa agents in human clinical trials (Table 1), but none of them has made significant progress. The antimicrobial peptide murepavadin failed in phase III clinical trials due to higher than expected acute kidney injuries [18]. Strictly speaking, amitriptyline and QPX7728 are not antibiotics. As an efflux pump inhibitor and $\beta$-lactamase inhibitor, respectively, they need to be administrated with other antibiotics. Emerging novel therapeutic strategies in discovery stages includes quorum sensing inhibition, use of iron chelators, and electrochemical scaffolds. However, only a few of them have entered into clinical trials $[19,20]$. From time to time, new antibiotics against Gram-negative pathogens are discovered, as recently exemplified by darobactin which was discovered from Photorhabdus symbionts of entomopathogenic nematode microbiomes and which may share similar requirements for antibiotics with humans [21]. Therefore, there 
is an urgent need to search for new antibiotics against drug-resistant bacteria to enable human beings to treat infectious diseases.

An investigation on global antibacterial pipeline claimed that over $70 \%$ of the projects aiming at new targets are working on antimicrobial peptides (AMPs), natural products, and LpxC inhibitors [22]. Marine natural products (MNPs) derived from marine organisms have proven to be one of the most valuable sources of bioactive small molecules. The marine environment is a special habitat rich in marine animals, plants, and microbes, which can biosynthesize a plethora of structurally unique compounds with significant bioactivities. Among the bioactive MNPs that have been discovered, many demonstrated antibacterial activities with distinctive mode of action. Herein, MNPs isolated in the last decade that are able to directly inhibit the growth or kill $P$. aeruginosa are summarized.

Table 1. Representative small molecules against $P$. aeruginosa in clinical trials ${ }^{\text {a }}$.

\begin{tabular}{|c|c|c|c|c|c|}
\hline ID & Structure & Phase & MOA $^{b}$ & Indication & Ref. \\
\hline murepavadin & & III & LptD inhibitor & $\begin{array}{l}\text { Lower respiratory } \\
\text { infection; Pneumonia }\end{array}$ & [23] \\
\hline fenretinide & & II & - & Cystic fibrosis & [24] \\
\hline amitriptyline & & II & $\begin{array}{l}\text { Efflux pump } \\
\text { inhibitor }\end{array}$ & $\begin{array}{l}\text { Cystic fibrosis; } \\
\text { Infection; } \\
\text { P. aeruginosa }\end{array}$ & [25] \\
\hline QPX7728 & & $\mathrm{I}$ & $\begin{array}{l}\beta \text {-lactamase } \\
\text { inhibitor }\end{array}$ & Bacterial infections & [26] \\
\hline
\end{tabular}

${ }^{\mathrm{a}}$ Up to date 11 November 2021 from https:// clinicaltrials.gov/. ${ }^{\mathrm{b}}$ MOA, mode of action.

\section{Emerging MNPs as Promising Antibiotics for Inhibiting P. aeruginosa}

Marine microbes account for over $98 \%$ of the ocean biomass. In order to survive in this biologically competitive environment, marine organisms may produce broad anti-microbial secondary metabolites, which are precious natural resources for the development of antibiotics. It is inevitable to screen the anti-bacterial effects of MNPs. However, inhibition of $P$. aeruginosa is not common. Based on the chemical structures, we have classified these MNPs into anthraquinones, macrolides, alkaloids, peptides, and other structures.

\subsection{Anthraquinones}

Mayamycin (1, Figure 2), an angucycline-type antibiotic belonging to aromatic polyketide, was identified from a Streptomyces sp. strain HB202 isolated from the marine sponge Halichondria panacea through variation of the culture conditions [27]. The production of aromatic polyketide mayamycin suggested that HB202 possesses type II polyketide synthases (PKS). Mayamycin glycosylated by a special aminosugar via C-glycosidic bond displayed not only good antibacterial activity against $P$. aeruginosa (DSM 50071) with an $\mathrm{IC}_{50}$ value of $2.5 \mu \mathrm{M}$, but also nanomolar range cytotoxicity against eight human cancer cell lines. Metal stress strategy $(100 \mu \mathrm{M}$ of nickel) was applied to marine Streptomyces pratensis strain NA-ZhouS1 and promoted the production of two new angucycline-type antibiotics with lower prevailing products in traditional culture. It was indicated that nickel stress was able to activate a silencing biosynthetic pathway. The new antibiotics stremycin A (2) and stremycin B (3) contained 1-position O-glycosylation and 9-position C-glycosylation as well as 
carbamoyl group attached to sugar C [28]. Both compounds exhibited anti-bacterial activities against $P$. aeruginosa with minimum inhibitory concentration (MIC) values of $16 \mu \mathrm{g} / \mathrm{mL}$.

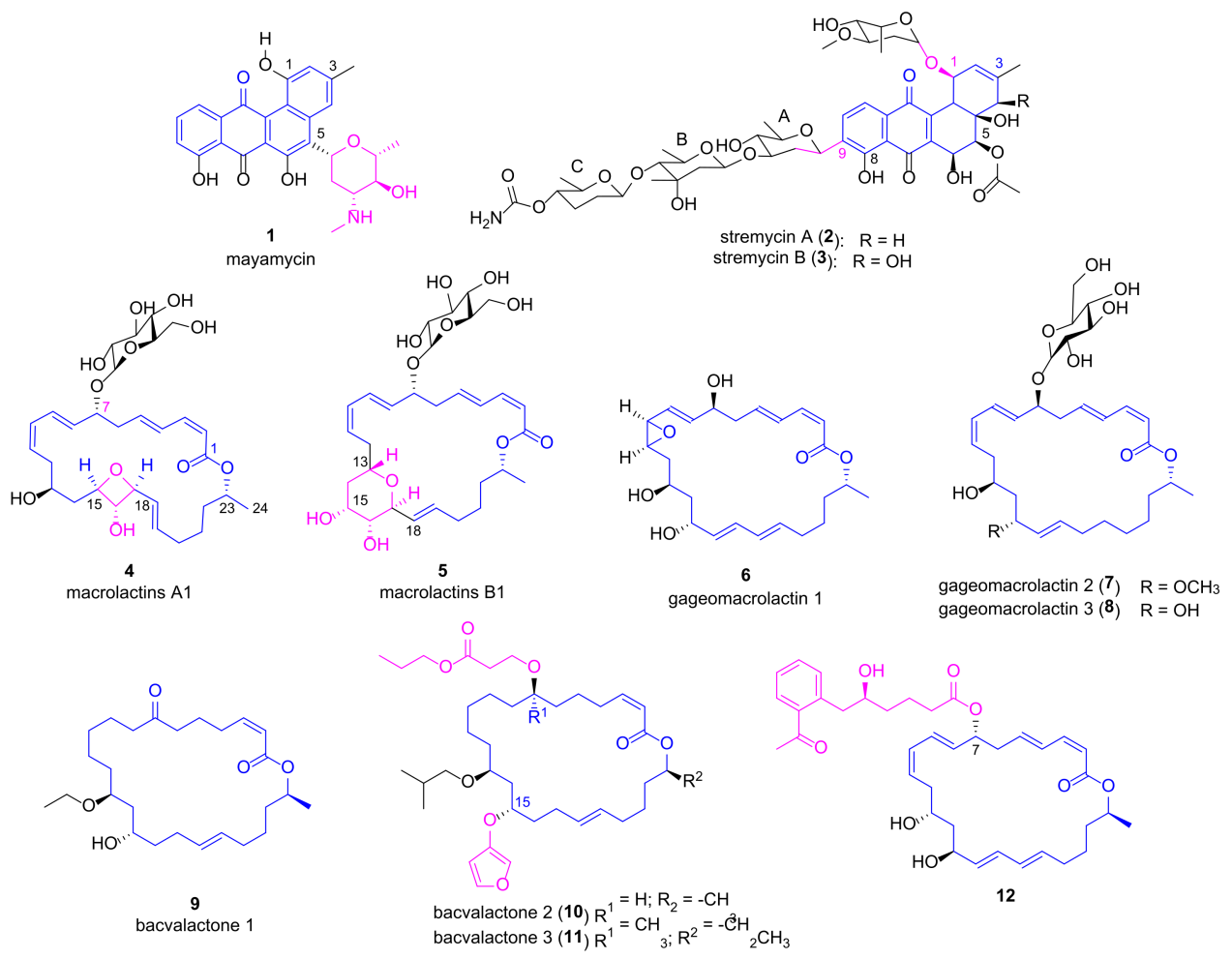

Figure 2. Chemical structures of anthraquinones 1 3 and macrolides 4 12.

\subsection{Macrolides}

MNPs macrolactins have been considered as good anti-microbials against both Grampositive and Gram-negative pathogenic bacteria by inhibiting peptidyl transferase [29]. Glycosylated 24-membered macrolactin A1 (4, Figure 2) and macrolactin B1 (5) containing oxetane and tetrahydropyran were discovered from two marine bacterial strains Bacillus sp. 09ID194 and Streptomyces sp. 06CH80 by Shin group [30,31]. Both compounds exhibited inhibitory effects against $P$. aeruginosa with MIC values of $32 \mu \mathrm{g} / \mathrm{mL}$. Another three 24-membered macrolactin derivatives gageomacrolactins $\mathbf{6} \sim \mathbf{8}$ isolated by the same group displayed much better potency against $P$. aeruginosa with MIC values ranging from $20 \mathrm{nM}$ to $50 \mathrm{nM}$, whereas no obvious cytotoxic effect was observed on a panel of cancer cell lines (e.g., HCT15 and MDA-MB-231) at the concentration of $30 \mu \mathrm{M}$ [32]. Bacvalactones 1 3 (9 11), belonging to 24-membered macrocyclic lactone family, were obtained from Bacillus amyloliquefaciens MTCC 12716, a symbiont of intertidal red algae Hypnea valentiae. It was proposed that these macrocyclic lactones were generated via a tran-acyltransferase (AT) PKS-assisted $m l n$ biosynthetic pathway. They showed better anti-P. aeruginosa activities (with inhibition zones of $17 \mathrm{~mm}, 23 \mathrm{~mm}$ and $25 \mathrm{~mm}$, respectively) than that of ampicillin $(7 \mathrm{~mm}$ ) [33]. The superior anti-microbial potency of 9 10 and $\mathbf{1 1}$ compared to ampicillin may attribute to the higher electronic parameter-polarizability (the ability of a molecule to respond to an electric field and acquire an electric dipole moment) [34]. Compound 11 exhibiting the most potent anti-bacterial activities (MIC value of $1.5 \mu \mathrm{g} / \mathrm{mL}$ against $P$. aeruginosa via microdilution method) has the highest polarizability, which may arise from the electron-rich $O$-furanyl, $O$-isobutyl, $O$-propyl propionate, and two additional methyl groups. In order to explore the mechanism of their in vitro bioactivities, molecular docking studies of 9 11 with $S$. aureus peptide deformylase (SaPDF) were performed [33]. Aryl-crowned polyketdie (12) bearing a 6'-(2" -acetylphenyl)-5'-hydroxyhexanoate group at C-7 position of macrolactin was purified from B. subtilis associated with brown seaweed Anthophycus longifolius [35]. It displayed comparable anti-bacterial effect against 
P. aeruginosa to positive controls (ampicillin, gentamicin, tetracycline, etc.) with inhibition zone of $15.7 \mathrm{~mm}$ and MIC value less than $13 \mu \mathrm{g} / \mathrm{mL}$. It was proposed that $12 \mathrm{might}$ inhibit pathogenic bacteria through forming a hexadentate $\mathrm{Fe}^{3+}$ coordination complex similar to siderophore mode of action [35].

Three elansolid-type of polyketide spanned 25-membered macrolides isobenzofuranyl (13, Figure 3) and furopyranyl (14 15), were discovered from marine B. amyloliquefaciens MTCC 12716, and anticipated to be biosynthesized through trans-AT polyketide synthase of type I PKS. They exhibited impressive anti-microbial activities against $P$. aeruginosa with MICs less than $1.0 \mu \mathrm{g} / \mathrm{mL}$ while the positive antibiotics (ampicillin and chloramphenicol) displayed the MICs more than $6.25 \mu \mathrm{g} / \mathrm{mL}$ [36]. Their in vitro bioactivities were explained through physicochemical parameter and molecular docking studies with SaPDF. Compound 14 has the high topological polar surface area [37] (tPSA, sum of surfaces of polar atoms in a molecule to show its ability to pass membrane) of 158.1, optimal $\log P$ value of 3.3, maximum number of hydrogen bond interactions and best drug-likeness score (the odd for a molecule to become a drug which can be predicted by software such as Molsoft ${ }^{\mathrm{TM}}$ ) of 0.98 , suggesting it is a promising lead antibiotic. Macrobrevin analogues 16 18 encompassing hexahydro-41-hydroxy-macrobrevin-31-acetate functionality were identified from B. amyloliquefaciens MTCC12713 via a bioactivity-guided purification strategy [38]. They displayed considerable anti-bacterial activities against $P$. aeruginos $a$ with the inhibition zones of $19 \mathrm{~mm}, 23 \mathrm{~mm}$ and $22 \mathrm{~mm}$, respectively, which is superior than those of positive antibiotics chloramphenicol, and ampicillin $(11 \mathrm{~mm})$. Among these polyketidespanned macrolides, compound $\mathbf{1 3}$ had the lowest MIC value $(1.56 \mu \mathrm{g} / \mathrm{mL})$, and its in silico docking study with SaPDF demonstrated a binding energy of $12.61 \mathrm{kcal} / \mathrm{mol}$ as well as an inhibition constant $\left(\mathrm{K}_{\mathrm{i}}\right)$ of $573.34 \mathrm{pM}$, implying that it is a promising antibiotic lead compound. Twenty-one membered macrocyclic lactones difficidin analogues 19 22, also isolated from the marine bacterium B. amyloliquefaciens MTCC12713, disclosed their significant bactericidal activities with clearance zone of $17 \mathrm{~mm}, 26 \mathrm{~mm}, 23 \mathrm{~mm}$ and $25 \mathrm{~mm}$, respectively [39]. Among them, compound 20 bearing 9-methyl-19-propyl dicarboxylate demonstrated MIC value of $4 \mathrm{nM}$ against $P$. aeruginosa and drug-likeness score of 0.35 . More comprehensive and in-depth studies are needed to validate their activities and investigate the mechanisms in detail. Traditionally, macrolide antibiotics were considered as protein synthesis inhibitors via targeting ribosome, but recent advances have revealed that they probably function as specific translation arrest cofactors [40].

\subsection{Macrocyclic Polyketide and Microketides}

Two new siderophore-type hydroxyfuranyl-benzoate spanned 12-membered macrocyclic polyketides $\mathbf{2 3}$ and $\mathbf{2 4}$ were isolated from Shewanella algae MTCC 12715, and displayed broad antibacterial activities against multiple clinical pathogens including MRSA (inhibition zones of $23 \mathrm{~mm}$ and $29 \mathrm{~mm}$, respectively) and P. aeruginosa (inhibition zones of $21 \mathrm{~mm}$ and $24 \mathrm{~mm}$, respectively) [41]. In order to verify their in vitro anti-microbial activities against MRSA, in silicon docking studies for $\mathbf{2 3}$ and $\mathbf{2 4}$ with penicillin-binding protein $2 \mathrm{a}$ (PBP2a), a transpeptidase that catalyzes cell-wall crosslinking to counter the effect of $\beta$-lactam antibiotics. Docking studies indicated that both compounds could occupy the allosteric site of PBP2a with predicted $\mathrm{K}_{\mathrm{i}}$ values of $17.51 \mathrm{nM}$ and $3.57 \mathrm{nM}$, respectively. Besides, compound 24 has a higher drug-likeness score of 0.91 than that of 23 [41].

A pair of epimeric polyketides $\mathbf{2 5}$ and $\mathbf{2 6}$ was discovered by our group from the gorgonian-derived fungus Microsphaeropsis sp. RA10-14, and both compounds showed pronounced and broad anti-bacterial activities with MIC values of 0.19 and $1.56 \mu \mathrm{g} / \mathrm{mL}$, respectively, against $P$. aeruginosa [42]. This result implied that S-configuration at C-11 position is more favorable for the anti-microbial effects. 

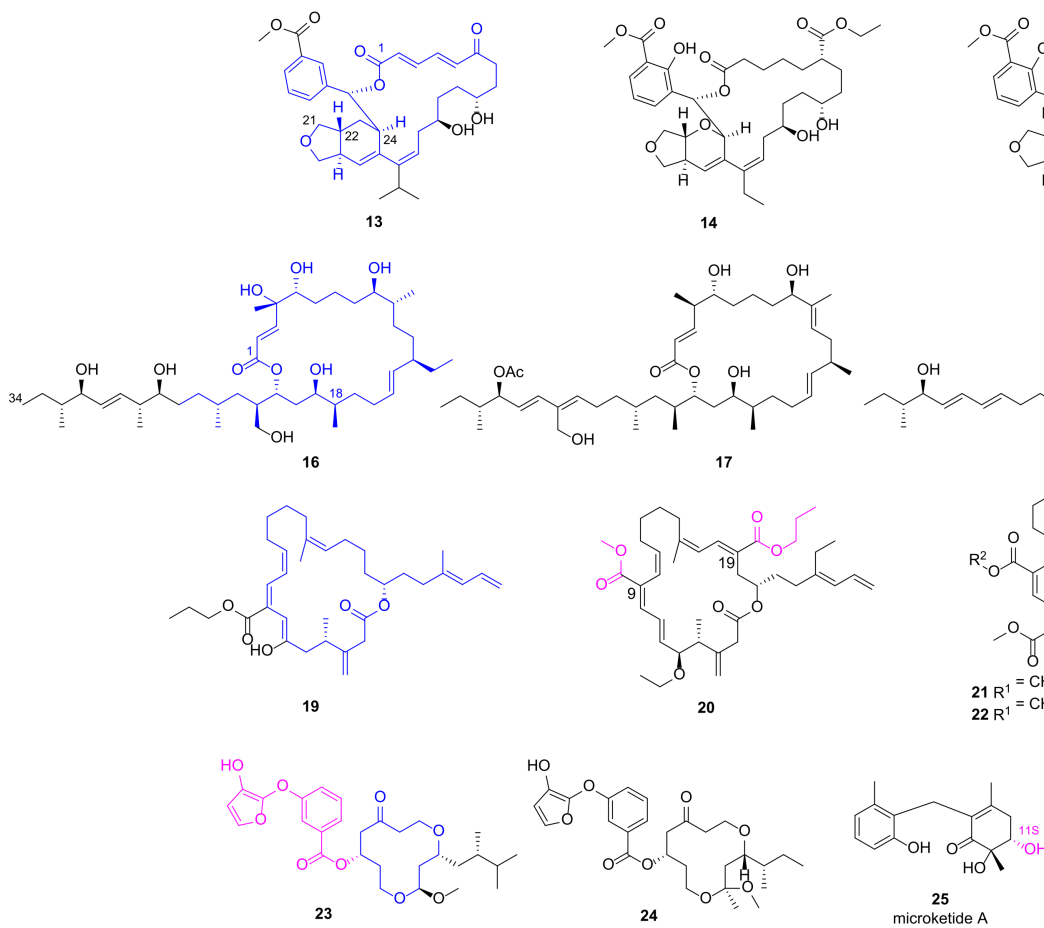
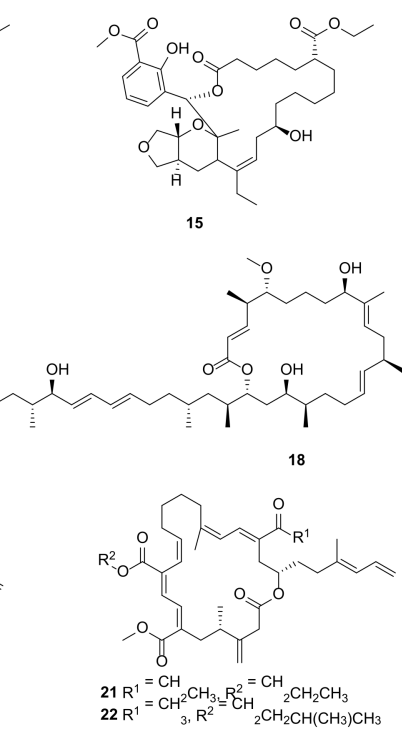

$21 \mathrm{R}^{1}=\mathrm{CH}^{2} \mathrm{CH}_{3}, \mathrm{R}^{2}=\mathrm{CH}_{2} \mathrm{CH}_{2} \mathrm{CH}_{3}$
$22 \mathrm{R}^{1}=\mathrm{CH}_{3}, \mathrm{R}^{2}=\mathrm{CH}_{2} \mathrm{CH}_{2} \mathrm{CH}\left(\mathrm{CH}_{3}\right) \mathrm{CH}_{3}$

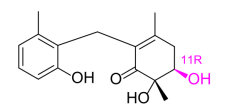

microketide B

Figure 3. Chemical structures of macrolides 13 22 and macrocyclic polyketides 23 26.

\subsection{Alkaloids}

3,4-Diarylpyrrole alkaloids denigrins A C (27 29, Figure 4) were isolated from the marine sponge Dendrilla nigra utilizing a bioactivity-guided strategy [43]. Compounds 28 and 29 showed anti-microbial activities against $P$. aeruginosa with MIC values of $25 \mu \mathrm{g} / \mathrm{mL}$ and $12.5 \mu \mathrm{g} / \mathrm{mL}$, respectively, while compound 27 lacking a p-hydroxyphenyl group at C-2 position just had a MIC value of $100 \mu \mathrm{g} / \mathrm{mL}$, implying that the p-hydroxyphenyl ring is important for the activity. More efforts are needed to illustrate their mechanism of action. Fascaplysin (30), a bis-indole alkaloid with multiple bioactivities, was originally discovered from marine sponge Fascaplysinopsis bergquist [44]. Zhidkov et al. designed and synthesized a series of brominated fascaplysins, and compound 31 exhibited potent and selective inhibitory activity toward P. aeruginosa with clearance zone more than $35 \mathrm{~mm}$ at the concentration of $0.2 \mathrm{mg} /$ disc [45]. It also demonstrated cytotoxic activity against melanoma cells SK-MEL-28 with an IC $_{50}$ value of $1.2 \mu \mathrm{M}$.

Jimemez group evaluated the anti-bacterial activities of several known pyrrole-imidazole alkaloids isolated from the sponge Agelas dilatata against multidrug resistance (MDR) pathogens including P. aeruginosa [46]. Bromoageliferin 32 containing two imidazoles and two pyrroles displayed good and specific inhibitory activity against $P$. aeruginosa ATCC27853 with an $\mathrm{IC}_{50}$ value of $8 \mu \mathrm{g} / \mathrm{mL}$. Moreover, it was effective on four strains of $P$. aeruginosa clinical isolates with a MIC value of $32 \mu \mathrm{g} / \mathrm{mL}$. Preliminary structureactivity-relationship (SAR) analysis implied that $\mathrm{Br}$ at the $\mathrm{C}-2$ position of pyrrole $\mathrm{A}$ ring was favorable, while the second $\mathrm{Br}$ at pyrrole $\mathrm{B}$ ring decreased the anti-bacterial activity. Furthermore, compound 32 was able to inhibit biofilm formation (30 40\%) of different pathogens at the concentration of $8 \mu \mathrm{g} / \mathrm{mL}$ and $16 \mu \mathrm{g} / \mathrm{mL}$. It also increased the survival time $(18.3 \mathrm{~h}$ vs. $13.5 \mathrm{~h})$ at the dose of $2 \mathrm{mg} / \mathrm{kg}$ in an in vivo Galleria mellonella model of P. aeruginosa ATCC27853 infection [46]. All of these findings make compound 32 a promising lead for the development of novel antibiotics specifically for P. aeruginosa.

The known compounds 33 34 (Figure 4) possessing diisocyanobuta-1,3-diene were re-isolated by Zhang group from Antarctic-derived Penicillium chrysogenum CCTCC M 2020019, and both compounds exhibited broad anti-bacterial activities [47]. Compound 33 has a MIC value of $0.125 \mu \mathrm{g} / \mathrm{mL}$ against $P$. aeruginosa, whereas the appendence of $\mathrm{OH}$ group 
(compound 34) decreased the anti-microbial activity obviously (MIC value of $8 \mu \mathrm{g} / \mathrm{mL}$ ). Meanwhile, both compounds were cytotoxic to cancer cell lines SF-268, MCF-7, HepG-2 and $\mathrm{A} 549$ with the $\mathrm{IC}_{50}$ values ranging from 0.26 to $5.04 \mu \mathrm{M}$ [47].
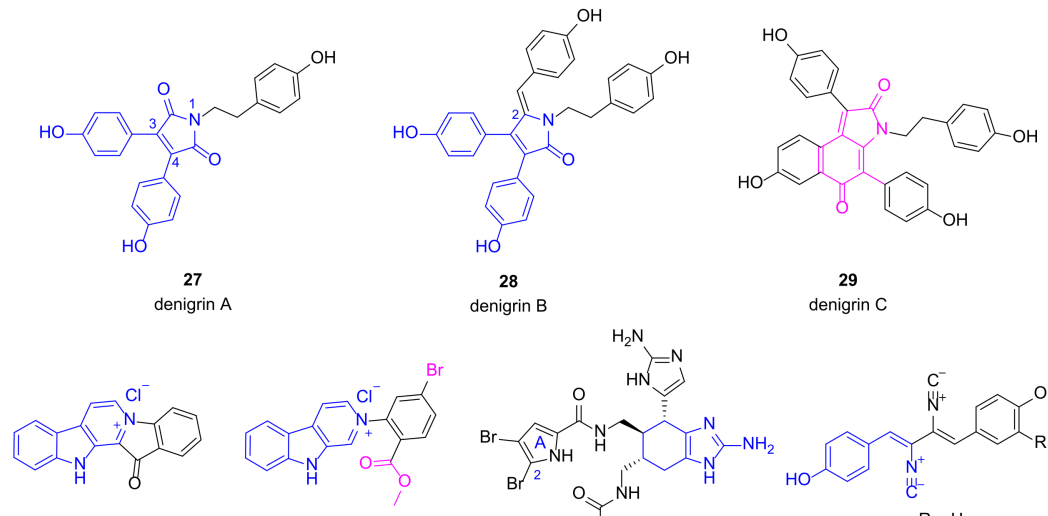

30

31

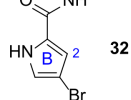

32
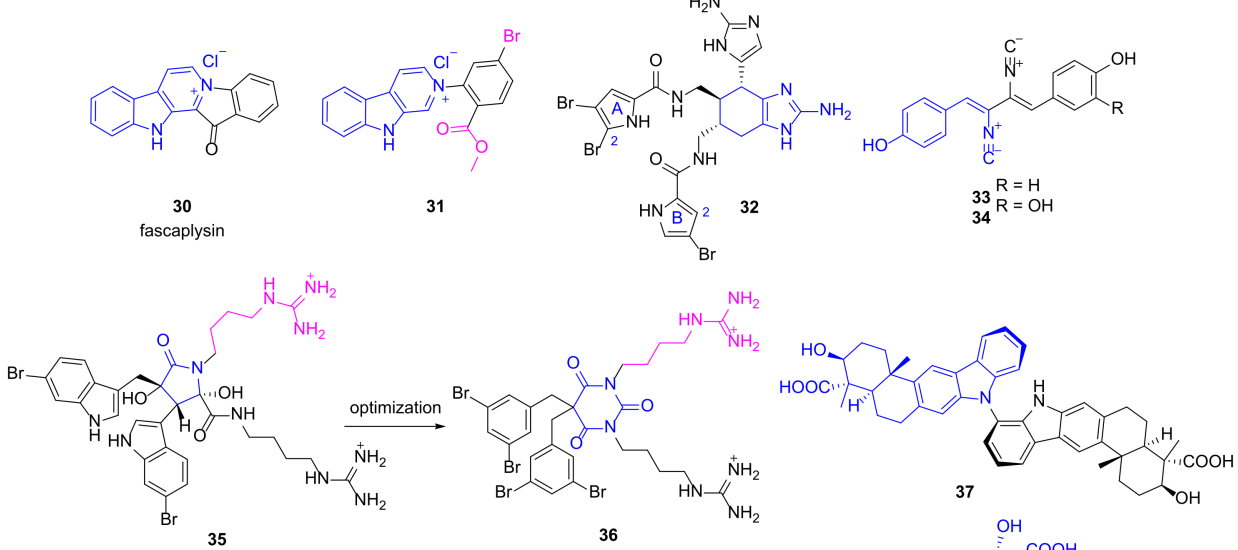

$\mathrm{OH}$
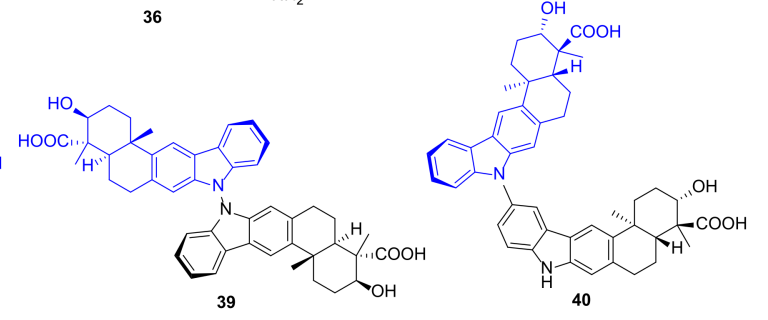

Figure 4. Chemical structures of alkaloids 27 40.

Paulsen and coworkers designed a series of cationic amphipathic barbiturates based on MNP eusynstyelamide (35) which is a moderate anti-microbial agent discovered from marine Arctic bryozoan Tegella cf. spitzbergensis and the Australian ascidian Eusynstyela latericius [48-50]. Among the synthesized derivatives, one compound (36) with a barbiturate ring replacing dihydroxybutyrolactam ring of MNP 35 showed promising anti-microbial activities against antibiotic susceptible pathogens and 30 multi-resistant clinical isolates including P. aeruginosa (MIC values of $4 \sim 16 \mu \mathrm{g} / \mathrm{mL}$ ) without obvious inhibition on human red blood cells $\left(\mathrm{EC}_{50}=62 \mu \mathrm{g} / \mathrm{mL}\right.$ ). It was also efficacious in mice infected with clinical isolates of Escherichia coli and Klebsiella pneumoniae. Mechanism studies via nuclear magnetic resonance and molecular dynamics simulations suggested that compound 36 took effects through disruption of membrane integrity [48]. Dixiamycins 37 40 were obtained from a cold-seep-derived actinomycete, Streptomyces olivaceus OUCLQ19-3 by Li group [51]. They all have dual bicyclic substructure fused with carbazole ring connecting via different sites, and exhibited anti-bacterial activities against $P$. aeruginosa with MIC values of 1.56, 1.56, 0.78 and $0.78 \mu \mathrm{g} / \mathrm{mL}$, respectively [51].

\subsection{Diphenyl Ethers and Phenols}

Polybrominated diphenyl ethers 41 and 42 (Figure 5) were discovered from the marine sponge Dysidea granulosa showing in vitro anti-microbial activities [52]. Compound $\mathbf{4 1}$ had a MIC value of $16 \mu \mathrm{g} / \mathrm{mL}$ against $P$. aeruginosa, whereas compound 42 with one more $\mathrm{Br}$ atom exhibited decreased inhibition against Gram-negative bacteria. The known diphenyl ethers 43 and 44 were re-isolated from marine algae-derived Aspergillus versicolor OUCMDZ- 
2738 cultured with $10 \mu \mathrm{M}$ of histone deacetylase inhibitor vorinostat in order to regulate the expression of gene clusters which may generate novel MNPs [53]. They specifically inhibited P. aeruginosa with MIC values of 17.4 and $13.9 \mu \mathrm{M}$, respectively. Phenolic polyketides 45 47 were obtained from antarctic sponge-derived fungus Penicillium sp. HDN151272 and can be oxidized to quinones $45^{\prime} \sim 47^{\prime}$ easily [54]. Compounds 46 (mixed with $46^{\prime}$ ) and 47 (mixed with $47^{\prime}$ ) demonstrated potent anti-P. aeruginosa activities with MIC values of 1.56 and $6.25 \mu \mathrm{g} / \mathrm{mL}$, respectively, whereas the MIC value of compound 45 (mixed with $45^{\prime}$ ) was more than $50 \mu \mathrm{g} / \mathrm{mL}$.

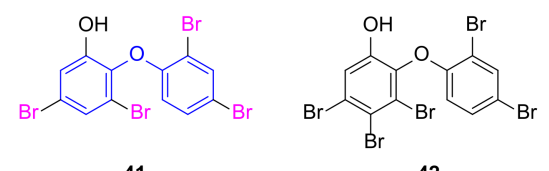

41<smiles>C/C(=C\CC(=O)Cl)CCc1cc(O)c(C)cc1O</smiles>

ketidocillinone $A(\mathbf{4 5}) \mathrm{R}=\mathrm{H}$ ketidocillinone $\mathrm{B}(\mathbf{4 6}) \mathrm{R}=\mathrm{CH}_{3}$

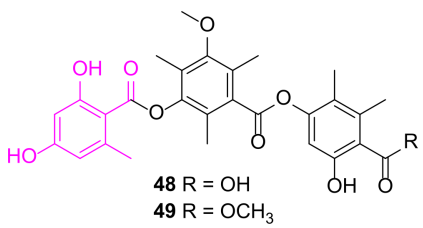

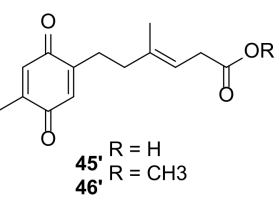

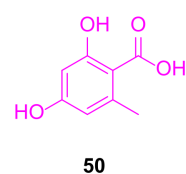

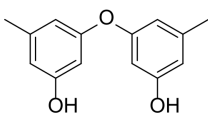

43

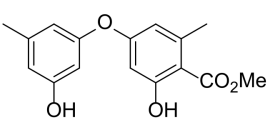

44

Figure 5. Chemical structures of phenols 41 52.

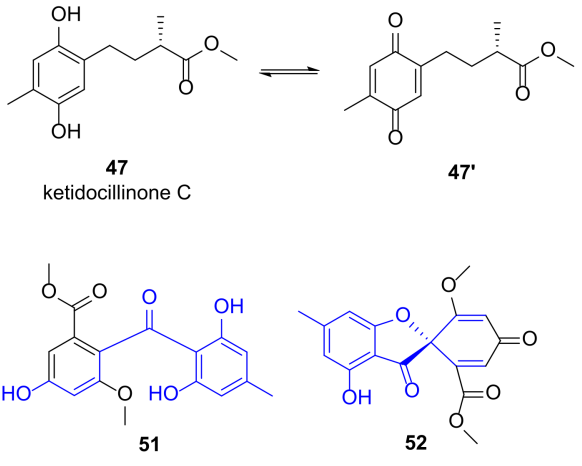

Polyketides $\mathbf{4 8} \mathbf{5 0}$ sharing a 2,4-dihydroxy-6-methylbenzoic acid fragment were isolated from the mangrove endophytic fungus Phoma sp. SYSU-SK-7 by She group displaying potent anti-microbial activities against $P$. aeruginosa with MIC values of 3.27, 1.67 and $2.10 \mu \mathrm{g} / \mathrm{mL}$, respectively [55]. Compounds 51 and 52, connecting two phenol groups by carbonyl group and spiro ring, respectively, was isolated by Shao group from soft coralderived fungus Aspergillus sp., and demonstrated good anti-microbial activities against P. aeruginosa with MIC values of 7.53 and $3.78 \mu \mathrm{M}$, respectively [56].

\subsection{Peptides}

AMPs as a diverse group of bioactive small peptides were believed to have broadspectrum activity and less favorable physiochemical properties (e.g., stability and bioavailability). AMPs can kill bacteria alone or synergize with conventional antibiotics. They are able to disrupt membrane integrity, suppress biofilm formation and modulate the host immune responses [57]. New findings and perspectives suggest that AMPs can be remarkably specific, and inferior stability of AMPs means less environmental persistence as well as fewer evolution of antibiotic resistance [58]. Resistance to AMPs results from multiple nonspecific mechanisms such as secretion of proteases and activation of efflux pumps, but AMPs still demonstrate less probability of resistance evolution since they kill bacteria faster and interact with bacterial cell surface rather than directly mutagenic [59,60]. Along with the advances on drug delivery and formulation, AMPs hold great potential combat MDR [61]. Epinecidin-1 (53, Figure 6) is a 20-amino-acid peptide produced by orange-spotted grouper Epinephelus coioides, playing an important role in protecting fish against Gram-positive and Gram-negative bacteria [62]. Moreover, it was found to be able to inhibit $P$. aeruginosa ATCCS19660 strain and MDR P. aeruginosa $\mathrm{R}$ strain with the MIC 90 (the MIC at which $90 \%$ of growth was inhibited) values of 50 and $3.12 \mu \mathrm{g} / \mathrm{mL}$, respectively. Then, its anti-bacterial efficacy in mouse infection models induced by P. aeruginosa was evaluated [63]. Compound 53 increased the survival rate of infected mice obviously and decreased the bacterial burden in all explored organs without systemic toxic effects. Besides, 
it was able to reduce the proinflammatory cytokines at protein and mRNA level. All of the results indicated that compound $\mathbf{5 3}$ is a promising lead compound as next generation antibiotic for treating MDR infections.

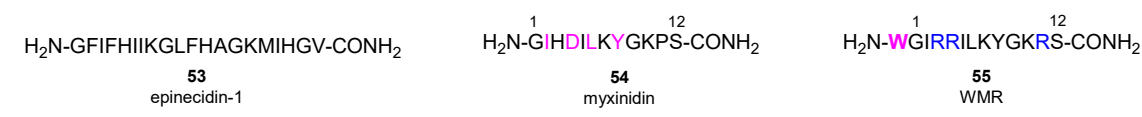

$\mathrm{H}_{2} \mathrm{~N}-\mathrm{TQQAFQKFLAAVTSALGKQYH-COOH}$ 56
SHBAP $\mathrm{H}_{2} \mathrm{~N}$-MAGGKAGKDSGKAKAKAVSRSARA
GLQFPVGRIHRHLK-COOH

58
Sphistin

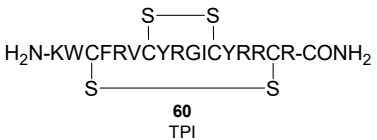

60
TPI

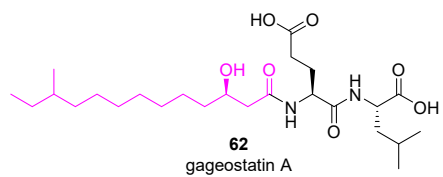

gageostatin A

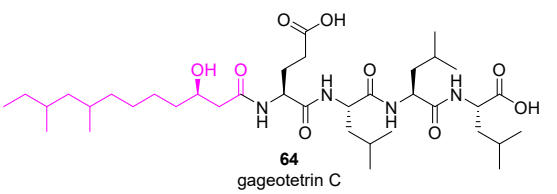
gageotetrin C

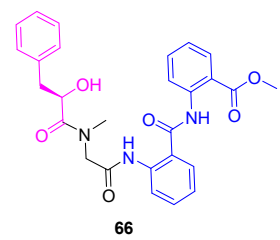

$\mathrm{H}_{2} \mathrm{~N}$-TQQAFQKFLAAVTSALGKQYH-CONH ${ }_{2}$

57

$\mathrm{H}_{2} \mathrm{~N}-\mathrm{KAKAKAVSRSARAGLQFPVGRIHRHLK-COOH}$

59
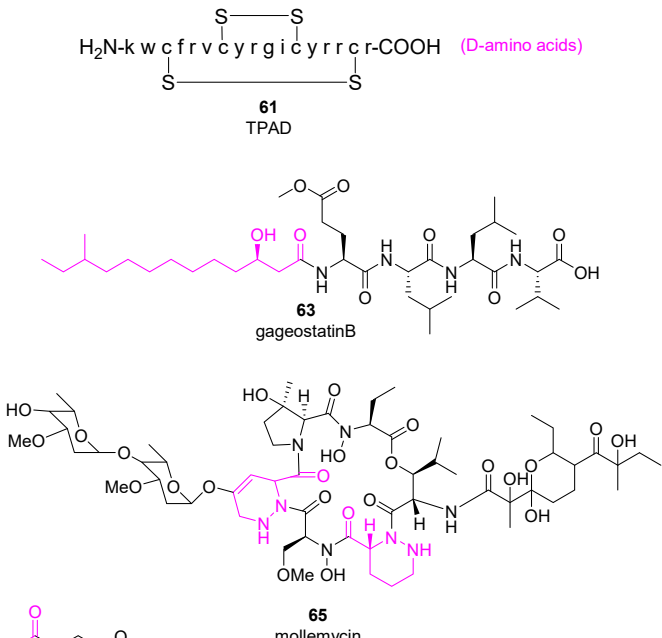

mollemycin

Figure 6. Chemical structures of anti-microbial peptides 53 67.

Myxinidin (54, Figure 6) is a 12-amino-acid peptide discovered from acidic epidermal mucus extract of hagfish Myxine glutinosa L. displaying anti-P. aeruginosa activities with the MBC (minimum bactericidal concentration) values about 7 10 $\mu \mathrm{g} / \mathrm{mL}$ [64]. A complete Ala scanning was executed for compound $\mathbf{5 4}$, and the results showed that amino acids at $\mathrm{C} 2, \mathrm{C} 4$, $\mathrm{C} 6, \mathrm{C} 8$, and $\mathrm{C} 12$ positions are essential for the anti-bacterial activity [65]. On the contrary, replacement of amino acids at $\mathrm{C} 1, \mathrm{C} 3, \mathrm{C} 5$, and $\mathrm{C} 11$ positions with alanine increased its anti-microbial activities against $P$. aeruginosa. Surprisingly, introduction of tryptophan at the $\mathrm{N}$-terminal and substitution of amino acids at $\mathrm{C} 3, \mathrm{C} 4$, and $\mathrm{C} 11$ positions with arginine (peptide 55) achieved the best potency. Meanwhile, they did not exhibit hemolytic activity at the concentration of $200 \mu \mathrm{M}$, suggesting they are promising lead antibiotics with fewer side effects.

Skipjack Hemoglobin $\beta$ chain-related peptide $\mathbf{5 6}$ was obtained from the liver of skipjack tuna Katsuwonus pelamis, which demonstrated anti-microbial activity against P. aeruginosa with a MIC value of $19 \mu \mathrm{g} / \mathrm{mL}$ without hemolytic activity, even though it cannot cross the bacterial membrane effectively [66]. The C-terminus amidated analogue 57 showed an improved anti-P. aeruginosa activity with a MIC value of $5.0 \mu \mathrm{g} / \mathrm{mL}$.

Sphistin (58, Figure 6), a 38-amino acid peptide based on a histone H2A identified from the mud crab Scylla paramamosain, exhibited broad anti-microbial activities without obvious cytotoxicity at the concentration of $100 \mu \mathrm{g} / \mathrm{mL}$ [67]. Its truncated fragment Sph12-38 (59) gained stronger anti-bacterial effects, and can not only disrupt the membrane 
integrity but also bind to Aeromonas sobria genome DNA at $6 \mu \mathrm{M}$ [68]. Both the original peptide 58 and its fragment 59 displayed anti-P. aeruginosa activities with the MICs of 24 and $12 \mu \mathrm{M}$, respectively. Conspicuously, when combined with azithromycin or rifampicin in vitro, both peptides displayed significant synergistic effects against $P$. aeruginosa with fractional inhibitory concentration (FIC, a measure of synergy) index ranging from 0.225 to 0.375 [69]. Surprisingly, mechanism study illustrated that combination of peptide 58 with azithromycin damaged the bacterial cell membrane completely and caused the leakage of cytoplasmic contents while the leakage was not observed in the case of combination of 58 with rifampicin. The in vivo efficacy of peptide 59 in combination with rifampicin or azithromycin was evaluated in a mouse wound model infected by P. aeruginosa. Compared to the phosphate-buffered saline (PBS) group, peptide 59 in combination with either rifampicin or azithromycin led to a complete recovery within five to seven or four to five days, while peptide 59 alone or the antibiotic alone could not shorten the healing time.

Tachyplesin I (TPI, 60) is a 14-amino acid $\beta$-hairpin anti-microbial peptide with two disulfide bonds originally isolated from the hepatocytes of Tachypleus tridentatus [70]. Replacement of all L-amino acids with D-amino acids in TPI generated TPAD (61) which retained the anti-microbial activity (MIC values about $8 \mu \mathrm{g} / \mathrm{mL}$ against $P$. aeruginosa) and showed improved enzymatic stability as well as decreased hemolytic activity [71]. Mechanism study revealed that the activation of the quorum sensing E. coli regulators $B$ and C (QseC/B) two-component system induced the bacterial resistance to peptide 61, while the combination of $\mathbf{6 1}$ with QseC/B inhibitor obviously increased the bactericidal effect against several multidrug-resistant bacteria.

Gageotetrins A-C (62 64, Figure 6), rare linear lipopeptides consisting of a 3-hydroxy fatty acid and di- or tetrapeptide, were isolated from a marine-derived B. subtilis, and exhibited good anti-microbial activities against $P$. aeruginosa with $\mathrm{MIC}$ values of $0.02-0.06 \mu \mathrm{M}$ by broth dilution assay [72]. It was speculated that 3-hydroxy fatty acid plays an important role for the anti-bacterial activities of compounds 62 64. Furthermore, none of them are toxic to human cancer cells at $30 \mu \mathrm{g} / \mathrm{mL}$. The first-in-class glyco-hexadepsipeptide polyketide mollemycin A (65) containing two piperazic acids was isolated from a marine-derived Streptomyces sp. CMB-M0244, which displayed impressive broad anti-bacterial activities against both Gram-positive and negative bacteria ( $\mathrm{IC}_{50}$ values of 10 50 nM) [73]. For P. aeruginosa, it has an $\mathrm{IC}_{50}$ value of $50 \mathrm{nM}$. Besides, it was able to inhibit drug-resistant malaria parasite Plasmodium falciparum with single-digit $\mathrm{IC}_{50}$ value without obvious cytotoxicity against mammalian cell line. Aminobenzoic peptides 66 and 67 were obtained from Ascidianderived endophytic fungus Aspergillus clavatus AS-107, demonstrating good anti-bacterial activities against $P$. aeruginosa with MIC values of 32.7 and $8.8 \mu \mathrm{g} / \mathrm{mL}$, respectively [74].

\subsection{Pyran Polyketides}

Polyene pyrone polyketides 68 70 (Figure 7), attaching a furanose or 2,5-dioxabicyclo [2.2.1] heptane pyrone backbone, were obtained from a marine fungus Penicillium sp. BB1122, which displayed anti-microbial activity against $P$. aeruginosa with MIC values of $4 \mu \mathrm{g} / \mathrm{mL}$ [75]. It was proposed that they may take effects via inhibiting RNA polymerase and disturbing RNA synthesis similar to myxopyronins. Pyran containing aromatic polyketides 71 74 were isolated from a marine Penicillium sp. RO-11 displaying potent anti-microbial activities against $P$. aeruginosa with MIC values of 5.2, 1.4, 4.7 and $2.9 \mu \mathrm{g} / \mathrm{mL}$, respectively [76].

\subsection{Polyether}

Ecteinamycin 75 (Figure 7) was a polyether antibiotic discovered from a marinederived Actinomadura sp. (strain WMMB499), displaying potent anti-bacterial activity against Clostridium difficile NAP1/B1/027 in vitro (MIC $=59 \mathrm{ng} / \mathrm{mL}$ ) and in vivo (mouse model, $30 \mathrm{ng}$ ecteinamycin in $100 \mu \mathrm{L}$ by oral gavage) [77]. Towards P. aeruginosa, compound 75 exhibited inhibited activity with a MIC value of $8.0 \mu \mathrm{g} / \mathrm{mL}$. It was revealed that com- 
pound 75 took effects as an ionophore antibiotic via potassium transport dysregulation based on E. coli chemical genomics results.<smiles>COc1cc(=O)oc(/C=C/C=C/C=C/C(C)=C/[C@@]2(C)O[C@H](C)C(O)(O)C2O)c1C</smiles>

68<smiles>COc1cc(O)c(C(=O)O)c(C2=COC(C(=O)O)=C[C@H]2C)c1</smiles><smiles>COc1cc(=O)oc(C(O)/C=C/C=C/C=C2\CC3(C)OC(C)(C(O)C2O)C3(C)C)c1C</smiles>

69

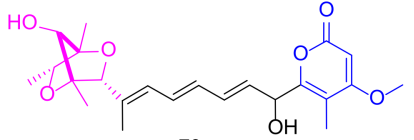

70<smiles>O=c1cc(CO)occ1O</smiles>

74
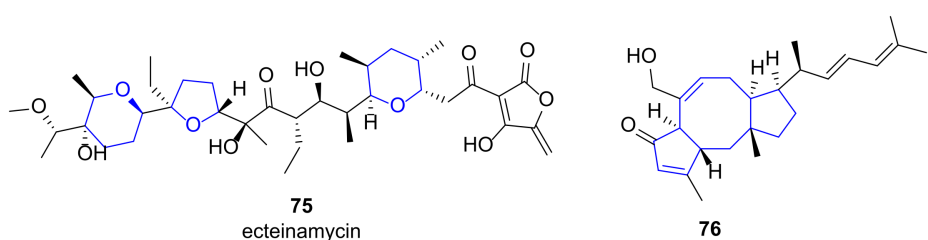

76<smiles></smiles>

73

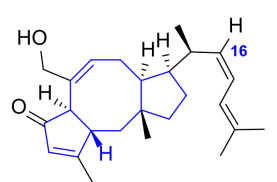

77
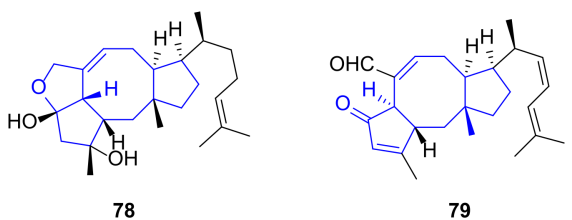

Figure 7. Chemical structures of pyran polyketides 68 74, ecteinamycin 75 and sesterterpenoids 76 79.

\subsection{Terpenoids}

Natural products terpenoids have long been discovered with great potential to inhibit microbes via multiple molecular mechanisms involving anti-quorum sensing and membrane disruption [78]. Ophiobolin sesterterpenoids 76 79 (Figure 7) were obtained from a deep-sea-derived fungus Aspergillus insuetus SD-512 by Wang group [79]. They all have a polycyclic ophiobolane skeleton and a double-bond-containing side chain. Compounds 77 79 demonstrated good anti-microbial activities against multiple pathogens including P. aeruginosa (MIC values of $8 \mu \mathrm{g} / \mathrm{mL}$ ), Vibrio alginolyticus (MIC values of $4 \mu \mathrm{g} / \mathrm{mL}$ ) and Vibrio vulnificus (MIC values of $8 \mu \mathrm{g} / \mathrm{mL}$ ), while compound 76 with a 16-trans configuration did show obvious anti-microbial activity (MIC $>32 \mu \mathrm{g} / \mathrm{mL}$ ) [79].

\section{Conclusions}

Oceans are a unique resource for bioactive natural products with great structural diversity and complexity. In a habitat in which microbes constitute $>98 \%$ of the biomass, many organisms produce antibacterial secondary metabolites to secure survival of the species. MNPs have an inherent high potential to contribute to the discovery and development of novel antibiotics to overcome drug resistance. Their unique chemical structures and explicit anti-bacterial activities probably imply cryptic and novel modes of actions. Thereby, they represent promising treatment of infections caused by Gram-negative bacteria such as $P$. aeruginosa, which has become one of the most threatened pathogens to human health without effective therapies.

In this review, we summarized MNPs discovered in the last decade that possess great potential to be developed as lead compounds for next-generation antibiotics. It is very interesting that for the MNPs we discussed here, most polyketides (e.g., anthraquinone, macrolides, macrocyclic polyketide and pyran polyketides) were discovered from various marine microbes including Bacillus sp., Aspergillus sp., and Penicillium sp., while alkaloids 
were mainly derived from marine invertebrates (e.g., marine sponge) and peptides were chiefly isolated from marine vertebrates (e.g., fish) (Figure 8). A variety of compounds showed impressive in vitro anti-bacterial activities against $P$. aeruginosa such as MNPs 13 15 $(\mathrm{MIC}<1 \mu \mathrm{g} / \mathrm{mL}), 20(\mathrm{MIC}=4 \mathrm{nM}), 25(\mathrm{MIC}=0.19 \mu \mathrm{g} / \mathrm{mL})$ and 39 40 $(0.78 \mu \mathrm{g} / \mathrm{mL})$. Several of them (e.g., 32) displayed good in vivo anti-microbial efficacies in infected animal models. Surprisingly, even though a good amount of MNPs as promising anti-bacterial compounds have been harvested, few novel antibiotics has been launched to the market in the last few decades. Undoubtedly, there are still many obstacles that have to be overcome to develop these hits or lead compounds into clinical drugs. Firstly, most of the MNPs are biologically evaluated preliminary via straightforward assays without further exploration. Thus, secondary assays to confirm their activities are indispensable. Secondly, scaling up of MNPs, which are usually obtained in a limited amount via organic total synthesis or biosynthesis, is needed to provide enough material for more comprehensive investigations on mode of actions and efficacy profiling. Thirdly, nearly all of the approved marine drugs are administrated intravascular, suggesting that the physiochemical properties of MNPs, such as metabolic stability and aqueous solubility, needs to be improved. Even if these MNPs cannot advance into the market, their novel and privileged scaffolds may still be utilized to design anti-bacterial agents. Fourthly, considering P. aeruginosa, we have to be aware about the uniqueness of the microbe and the underlying molecular mechanisms of antibiotics, which will enable us to kill $P$. aeruginosa using monotherapy or combination therapy [80]. Additionally, the key factors influencing the transport and accumulation of small molecular antibiotics must be taken into account. It seems that the recent predicted compound accumulation rules do not apply to P. aeruginosa [81]. Finally, rather than kill or inhibit P. aeruginosa directly, indirect strategies (e.g., quorum-sensing inhibitors and antibiofilm formation) able to enhance the potency of existing antibiotics should be taken into consideration [82-84]. In a word, MNPs are anticipated to play important roles and help take a lead in the arms race between bacteria and antibiotics.
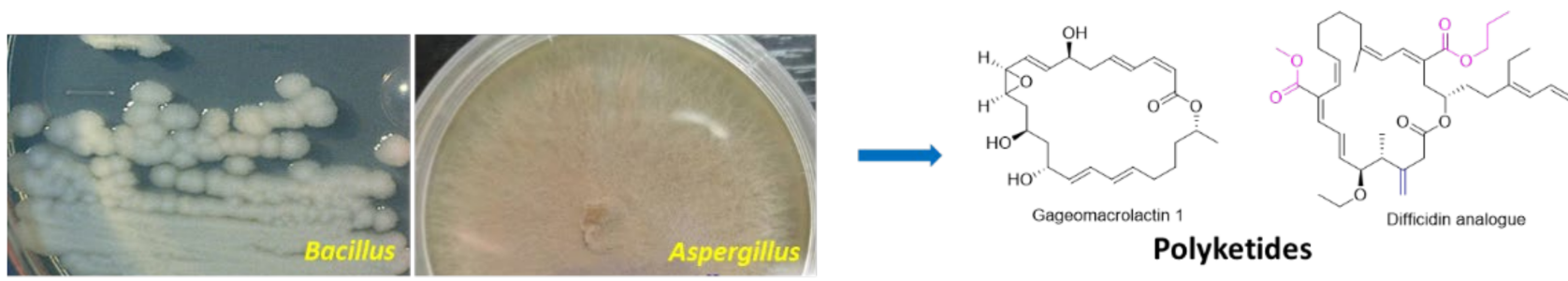

Polyketides
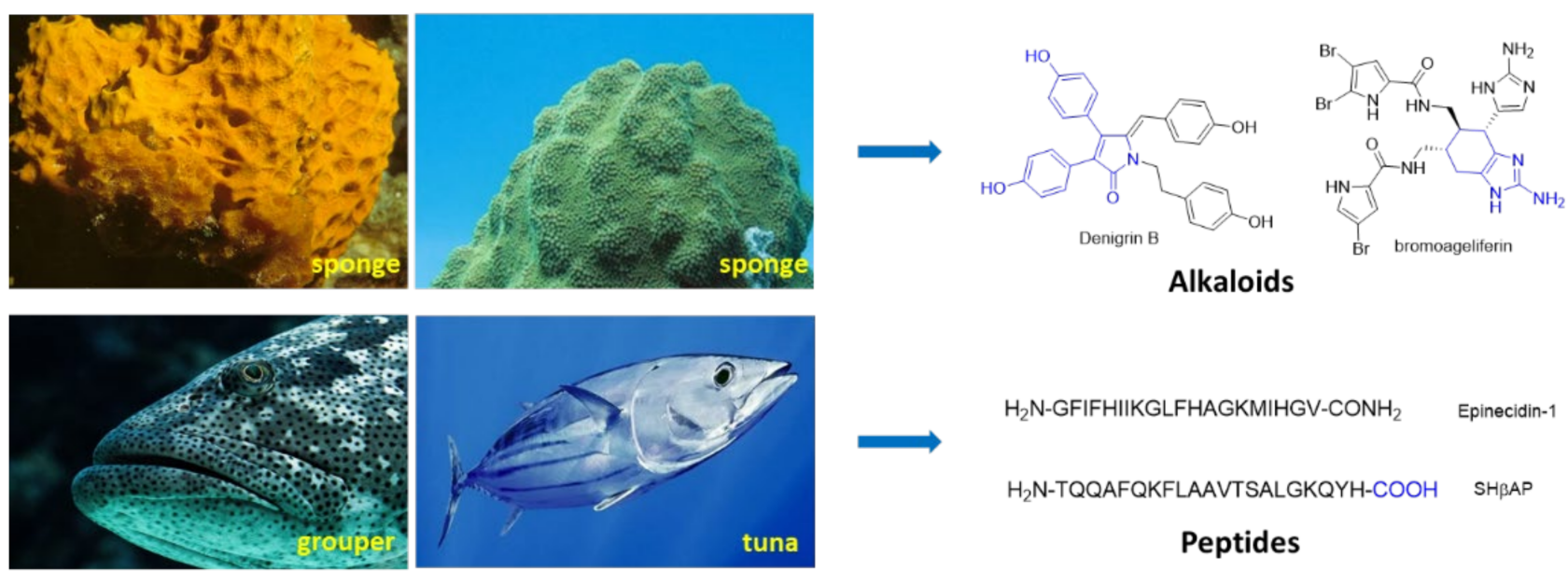

Alkaloids

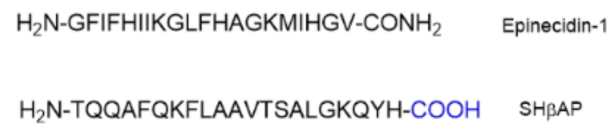

Peptides

Figure 8. Representative marine organisms producing antibiotics. 


\begin{abstract}
Author Contributions: Conceptualization, Z.L.; writing —original draft preparation, Z.L., H.L. (Haoran Li) and M.M.; writing-review and editing, Y.Z., H.L. (Huaxuan Li), P.W., Y.L. and C.-Y.W.; supervision, T.F.S., P.W. and C.-Y.W.; funding acquisition, C.-Y.W. and Z.L. All authors have read and agreed to the published version of the manuscript.

Funding: This research was funded by National Natural Science Foundation of China under the projects of Nos. 42176109 (Z.L.), 41830535 (C.-Y.W.) and 81874300 (C.-Y.W.). Research in the Schäberle lab was supported by the German Center of Infection Research (DZIF) and the Hessen State Ministry of Higher Education, Research and the Arts (HMWK) via the LOEWE Center for Insect Biotechnology and Bioresources.
\end{abstract}

Conflicts of Interest: The authors declare no conflict of interest.

\title{
References
}

1. Etebu, E.; Arikekpar, I. Antibiotics: Classification and mechanisms of action with emphasis on molecular perspectives. Int. J. Appl. Microbiol. Biotechnol. Res. 2016, 4, 90-101.

2. Arzanlou, M.; Chai, W.C.; Venter, H. Intrinsic, adaptive and acquired antimicrobial resistance in Gram-negative bacteria. Essays Biochem. 2017, 61, 49-59. [CrossRef] [PubMed]

3. Vivas, R.; Barbosa, A.A.T.; Dolabela, S.S.; Jain, S. Multidrug-resistant bacteria and alternative methods to control them: An overview. Microb. Drug Resist. 2019, 25, 890-908. [CrossRef] [PubMed]

4. WHO Publishes List of Bacteria for Which New Antibiotics Are Urgently Needed. Available online: https://www.who.int/news / item/27-02-2017-who-publishes-list-of-bacteria-for-which-new-antibiotics-are-urgently-needed (accessed on 27 February 2017).

5. Paterson, D.L. The epidemiological profile of infections with multidrug-resistant Pseudomonas aeruginosa and Acinetobacter species. Clin. Infect. Dis. 2006, 43 (Suppl. 2), S43-S48. [CrossRef]

6. Lyczak, J.B.; Cannon, C.L.; Pier, G.B. Establishment of Pseudomonas aeruginosa infection: Lessons from a versatile opportunist. Microbes Infect. 2000, 2, 1051-1060. [CrossRef]

7. Wagner, V.E.; Iglewski, B.H. P. aeruginosa biofilms in CF infection. Clin. Rev. Allergy Immunol. 2008, 35, 124-134. [CrossRef] [PubMed]

8. Simpson, B.W.; Trent, M.S. Pushing the envelope: LPS modifications and their consequences. Nat. Rev. Microbiol. 2019, 17, 403-416. [CrossRef] [PubMed]

9. Li, X.Z.; Plesiat, P.; Nikaido, H. The challenge of efflux-mediated antibiotic resistance in Gram-negative bacteria. Clin. Microbiol. Rev. 2015, 28, 337-418. [CrossRef]

10. Nikaido, H.; Pages, J.M. Broad-specificity efflux pumps and their role in multidrug resistance of Gram-negative bacteria. FEMS Microbiol. Rev. 2012, 36, 340-363. [CrossRef] [PubMed]

11. Srikumar, R.; Paul, C.J.; Poole, K. Influence of mutations in the mexR repressor gene on expression of the MexA-MexB-oprM multidrug efflux system of Pseudomonas aeruginosa. J. Bacteriol. 2000, 182, 1410-1414. [CrossRef] [PubMed]

12. Bruchmann, S.; Dotsch, A.; Nouri, B.; Chaberny, I.F.; Haussler, S. Quantitative contributions of target alteration and decreased drug accumulation to Pseudomonas aeruginosa fluoroquinolone resistance. Antimicrob. Agents Chemother. 2013, 57, 1361-1368. [CrossRef] [PubMed]

13. Berrazeg, M.; Jeannot, K.; Ntsogo Enguene, V.Y.; Broutin, I.; Loeffert, S.; Fournier, D.; Plesiat, P. Mutations in beta-lactamase AmpC increase resistance of Pseudomonas aeruginosa isolates to antipseudomonal cephalosporins. Antimicrob. Agents Chemother. 2015, 59, 6248-6255. [CrossRef]

14. Fernandez, L.; Hancock, R.E. Adaptive and mutational resistance: Role of porins and efflux pumps in drug resistance. Clin. Microbiol. Rev. 2012, 25, 661-681. [CrossRef] [PubMed]

15. Mulcahy, L.R.; Burns, J.L.; Lory, S.; Lewis, K. Emergence of Pseudomonas aeruginosa strains producing high levels of persister cells in patients with cystic fibrosis. J. Bacteriol. 2010, 192, 6191-6199. [CrossRef] [PubMed]

16. Morel, C.M.; Lindahl, O.; Harbarth, S.; de Kraker, M.E.A.; Edwards, S.; Hollis, A. Industry incentives and antibiotic resistance: An introduction to the antibiotic susceptibility bonus. J. Antibiot. 2020, 73, 421-428. [CrossRef] [PubMed]

17. Bassetti, M.; Echols, R.; Matsunaga, Y.; Ariyasu, M.; Doi, Y.; Ferrer, R.; Lodise, T.P.; Naas, T.; Niki, Y.; Paterson, D.L.; et al. Efficacy and safety of cefiderocol or best available therapy for the treatment of serious infections caused by carbapenem-resistant Gram-negative bacteria (CREDIBLE-CR): A randomised, open-label, multicentre, pathogen-focused, descriptive, phase 3 trial. Lancet Infect. Dis. 2021, 21, 226-240. [CrossRef]

18. Dijksteel, G.S.; Ulrich, M.M.W.; Middelkoop, E.; Boekema, B. Review: Lessons learned from clinical trials using antimicrobial peptides (AMPs). Front. Microbiol. 2021, 12, 616979. [CrossRef] [PubMed]

19. Hurley, M.N.; Camara, M.; Smyth, A.R. Novel approaches to the treatment of Pseudomonas aeruginosa infections in cystic fibrosis. Eur. Respir. J. 2012, 40, 1014-1023. [CrossRef]

20. Liu, J.; Hou, J.S.; Chang, Y.Q.; Peng, L.J.; Zhang, X.Y.; Miao, Z.Y.; Sun, P.H.; Lin, J.; Chen, W.M. New Pqs Quorum Sensing System Inhibitor as an Antibacterial Synergist against Multidrug-Resistant Pseudomonas aeruginosa. J. Med. Chem. 2022, 65, 688-709. [CrossRef] [PubMed] 
21. Imai, Y.; Meyer, K.J.; Iinishi, A.; Favre-Godal, Q.; Green, R.; Manuse, S.; Caboni, M.; Mori, M.; Niles, S.; Ghiglieri, M.; et al. A new antibiotic selectively kills Gram-negative pathogens. Nature 2019, 576, 459-464. [CrossRef] [PubMed]

22. Theuretzbacher, U.; Outterson, K.; Engel, A.; Karlen, A. The global preclinical antibacterial pipeline. Nat. Rev. Microbiol. 2020, 18, 275-285. [CrossRef] [PubMed]

23. Andolina, G.; Bencze, L.C.; Zerbe, K.; Muller, M.; Steinmann, J.; Kocherla, H.; Mondal, M.; Sobek, J.; Moehle, K.; Malojcic, G.; et al. A peptidomimetic antibiotic interacts with the periplasmic domain of LptD from Pseudomonas aeruginosa. ACS Chem. Biol. 2018, 13, 666-675. [CrossRef] [PubMed]

24. Garic, D.; De Sanctis, J.B.; Dumut, D.C.; Shah, J.; Pena, M.J.; Youssef, M.; Petrof, B.J.; Kopriva, F.; Hanrahan, J.W.; Hajduch, M.; et al. Fenretinide favorably affects mucins (MUC5AC/MUC5B) and fatty acid imbalance in a manner mimicking CFTR-induced correction. BBA Mol. Cell Biol. Lipids 2020, 1865, 158538. [CrossRef] [PubMed]

25. Grimsey, E.M.; Fais, C.; Marshall, R.L.; Ricci, V.; Ciusa, M.L.; Stone, J.W.; Ivens, A.; Malloci, G.; Ruggerone, P.; Vargiu, A.V.; et al. Chlorpromazine and amitriptyline are substrates and inhibitors of the AcrB multidrug efflux pump. mBio 2020, 11, e00465-20. [CrossRef] [PubMed]

26. Lomovskaya, O.; Tsivkovski, R.; Nelson, K.; Rubio-Aparicio, D.; Sun, D.; Totrov, M.; Dudley, M.N. Spectrum of beta-lactamase inhibition by the cyclic boronate QPX7728, an ultrabroad-spectrum beta-lactamase inhibitor of serine and metallo-beta-lactamases: Enhancement of activity of multiple antibiotics against isogenic strains expressing single beta-lactamases. Antimicrob. Agents Chemother. 2020, 64, e00212-20. [CrossRef] [PubMed]

27. Schneemann, I.; Kajahn, I.; Ohlendorf, B.; Zinecker, H.; Erhard, A.; Nagel, K.; Wiese, J.; Imhoff, J.F. Mayamycin, a cytotoxic polyketide from a Streptomyces strain isolated from the marine sponge Halichondria panicea. J. Nat. Prod. 2010, 73, 1309-1312. [CrossRef] [PubMed]

28. Akhter, N.; Liu, Y.; Auckloo, B.N.; Shi, Y.; Wang, K.; Chen, J.; Wu, X.; Wu, B. Stress-driven discovery of new angucycline-type antibiotics from a marine Streptomyces pratensis NA-ZhouS1. Mar. Drugs 2018, 16, 331. [CrossRef]

29. Zheng, C.J.; Lee, S.; Lee, C.H.; Kim, W.G. Macrolactins O-R, glycosylated 24-membered lactones from Bacillus sp. AH159-1. J. Nat. Prod. 2007, 70, 1632-1635. [CrossRef]

30. Mondol, M.A.; Tareq, F.S.; Kim, J.H.; Lee, M.; Lee, H.S.; Lee, Y.J.; Lee, J.S.; Shin, H.J. Cyclic ether-containing macrolactins, antimicrobial 24-membered isomeric macrolactones from a marine Bacillus sp. J. Nat. Prod. 2011, 74, 2582-2587. [CrossRef]

31. Mondol, M.A.; Shin, H.J. Antibacterial and antiyeast compounds from marine-derived bacteria. Mar. Drugs 2014, 12, $2913-2921$. [CrossRef]

32. Tareq, F.S.; Kim, J.H.; Lee, M.A.; Lee, H.S.; Lee, J.S.; Lee, Y.J.; Shin, H.J. Antimicrobial gageomacrolactins characterized from the fermentation of the marine-derived bacterium Bacillus subtilis under optimum growth conditions. J. Agric. Food Chem. 2013, 61, 3428-3434. [CrossRef] [PubMed]

33. Chakraborty, K.; Kizhakkekalam, V.K.; Joy, M.; Chakraborty, R.D. Moving away from traditional antibiotic treatment: Can macrocyclic lactones from marine macroalga-associated heterotroph be the alternatives? Appl. Microbiol. Biotechnol. 2020, 104, 7117-7130. [CrossRef] [PubMed]

34. Gillet, A.; Cher, S.; Tasse, M.; Blon, T.; Alves, S.; Izzet, G.; Chaudret, B.; Proust, A.; Demont, P.; Volatron, F.; et al. Polarizability is a key parameter for molecular electronics. Nanoscale Horiz. 2021, 6, 271-276. [CrossRef] [PubMed]

35. Chakraborty, K.; Thilakan, B.; Kizhakkekalam, V.K. Antibacterial aryl-crowned polyketide from Bacillus subtilis associated with seaweed Anthophycus longifolius. J. Appl. Microbiol. 2018, 124, 108-125. [CrossRef] [PubMed]

36. Kizhakkekalam, V.K.; Chakraborty, K.; Joy, M. Oxygenated elansolid-type of polyketide spanned macrolides from a marine heterotrophic Bacillus as prospective antimicrobial agents against multidrug-resistant pathogens. Int. J. Antimicrob. Agents 2020, 55, 105892. [CrossRef]

37. Ertl, P.; Rohde, B.; Selzer, P. Fast calculation of molecular polar surface area as a sum of fragment-based contributions and its application to the prediction of drug transport properties. J. Med. Chem. 2000, 43, 3714-3717. [CrossRef]

38. Chakraborty, K.; Kizhakkekalam, V.K.; Joy, M. Polyketide-derived macrobrevins from marine macroalga-associated Bacillus amyloliquefaciens as promising antibacterial agents against pathogens causing nosocomial infections. Phytochemistry 2021, 193, 112983. [CrossRef]

39. Chakraborty, K.; Kizhakkekalam, V.K.; Joy, M.; Dhara, S. Difficidin class of polyketide antibiotics from marine macroalgaassociated Bacillus as promising antibacterial agents. Appl. Microbiol. Biotechnol. 2021, 105, 6395-6408. [CrossRef]

40. Vazquez-Laslop, N.; Mankin, A.S. How macrolide antibiotics work. Trends Biochem. Sci. 2018, 43, 668-684. [CrossRef]

41. Chakraborty, K.; Kizhakkekalam, V.K.; Joy, M. Macrocyclic polyketides with siderophore mode of action from marine heterotrophic Shewanella algae: Prospective anti-infective leads attenuate drug-resistant pathogens. J. Appl. Microbiol. 2021, 130, 1552-1570. [CrossRef] [PubMed]

42. Liu, Y.F.; Zhang, Y.H.; Shao, C.L.; Cao, F.; Wang, C.Y. Microketides A and B, polyketides from a gorgonian-derived Microsphaeropsis sp. Fungus. J. Nat. Prod. 2020, 83, 1300-1304. [CrossRef] [PubMed]

43. Murali Krishna Kumar, M.; Devilal Naik, J.; Satyavathi, K.; Ramana, H.; Raghuveer Varma, P.; Purna Nagasree, K.; Smitha, D.; Venkata Rao, D. Denigrins A-C: New antitubercular 3,4-diarylpyrrole alkaloids from Dendrilla nigra. Nat. Prod. Res. 2014, 28, 888-894. [CrossRef] [PubMed]

44. Bharate, S.B.; Manda, S.; Mupparapu, N.; Battini, N.; Vishwakarma, R.A. Chemistry and biology of fascaplysin, a potent marine-derived CDK-4 inhibitor. Mini. Rev. Med. Chem. 2012, 12, 650-664. [CrossRef] [PubMed] 
45. Zhidkov, M.E.; Smirnova, P.A.; Tryapkin, O.A.; Kantemirov, A.V.; Khudyakova, Y.V.; Malyarenko, O.S.; Ermakova, S.P.; Grigorchuk, V.P.; Kaune, M.; Amsberg, G.V.; et al. Total syntheses and preliminary biological evaluation of brominated fascaplysin and reticulatine alkaloids and their analogues. Mar. Drugs 2019, 17, 496. [CrossRef] [PubMed]

46. Pech-Puch, D.; Perez-Povedano, M.; Martinez-Guitian, M.; Lasarte-Monterrubio, C.; Vazquez-Ucha, J.C.; Bou, G.; Rodriguez, J.; Beceiro, A.; Jimenez, C. In vitro and in vivo assessment of the efficacy of bromoageliferin, an alkaloid isolated from the sponge Agelas dilatata, against Pseudomonas aeruginosa. Mar. Drugs 2020, 18, 326. [CrossRef] [PubMed]

47. Khan, I.; Zhang, H.; Liu, W.; Zhang, L.; Peng, F.; Chen, Y.; Zhang, Q.; Zhang, G.; Zhang, W.; Zhang, C. Identification and bioactivity evaluation of secondary metabolites from Antarctic-derived Penicillium chrysogenum CCTCC M 2020019. RSC Adv. 2020, 10, 20738-20744. [CrossRef]

48. Paulsen, M.H.; Engqvist, M.; Ausbacher, D.; Anderssen, T.; Langer, M.K.; Haug, T.; Morello, G.R.; Liikanen, L.E.; Blencke, H.M.; Isaksson, J.; et al. Amphipathic barbiturates as mimics of antimicrobial peptides and the marine natural products eusynstyelamides with activity against multi-resistant clinical isolates. J. Med. Chem. 2021, 64, 11395-11417. [CrossRef]

49. Tadesse, M.; Tabudravu, J.N.; Jaspars, M.; Strom, M.B.; Hansen, E.; Andersen, J.H.; Kristiansen, P.E.; Haug, T. The antibacterial ent-eusynstyelamide B and eusynstyelamides D, E, and F from the Arctic bryozoan Tegella cf. spitzbergensis. J. Nat. Prod. 2011, 74, 837-841. [CrossRef]

50. Tapiolas, D.M.; Bowden, B.F.; Abou-Mansour, E.; Willis, R.H.; Doyle, J.R.; Muirhead, A.N.; Liptrot, C.; Llewellyn, L.E.; Wolff, C.W.; Wright, A.D.; et al. Eusynstyelamides A, B, and C, nNOS inhibitors, from the ascidian Eusynstyela latericius. J. Nat. Prod. 2009, 72, 1115-1120. [CrossRef]

51. Jin, E.; Li, H.; Liu, Z.; Xiao, F.; Li, W. Antibiotic dixiamycins from a cold-seep-derived Streptomyces olivaceus. J. Nat. Prod. 2021, 84, 2606-2611. [CrossRef]

52. Sun, S.; Canning, C.B.; Bhargava, K.; Sun, X.; Zhu, W.; Zhou, N.; Zhang, Y.; Zhou, K. Polybrominated diphenyl ethers with potent and broad spectrum antimicrobial activity from the marine sponge Dysidea. Bioorg. Med. Chem. Lett. 2015, 25, 2181-2183. [CrossRef] [PubMed]

53. Liu, W.; Wang, L.; Wang, B.; Xu, Y.; Zhu, G.; Lan, M.; Zhu, W.; Sun, K. Diketopiperazine and diphenylether derivatives from marine algae-derived Aspergillus versicolor OUCMDZ-2738 by epigenetic activation. Mar. Drugs 2018, 17, 6. [CrossRef]

54. Shah, M.; Sun, C.; Sun, Z.; Zhang, G.; Che, Q.; Gu, Q.; Zhu, T.; Li, D. Antibacterial polyketides from antarctica sponge-derived fungus Penicillium sp. HDN151272. Mar. Drugs 2020, 18, 71. [CrossRef] [PubMed]

55. Chen, Y.; Yang, W.; Zou, G.; Chen, S.; Pang, J.; She, Z. Bioactive polyketides from the mangrove endophytic fungi Phoma sp. SYSU-SK-7. Fitoterapia 2019, 139, 104369. [CrossRef]

56. Said, G.; Hou, X.-M.; Liu, X.; Chao, R.; Jiang, Y.-Y.; Zheng, J.-Y.; Shao, C.-L. Antimicrobial and cytotoxic activities of secondary metabolites from the soft coral derived fungus Aspergillus sp. Chem. Nat. Compd. 2019, 55, 531-533. [CrossRef]

57. Magana, M.; Pushpanathan, M.; Santos, A.L.; Leanse, L.; Fernandez, M.; Ioannidis, A.; Giulianotti, M.A.; Apidianakis, Y.; Bradfute, S.; Ferguson, A.L.; et al. The value of antimicrobial peptides in the age of resistance. Lancet Infect. Dis. 2020, 20, e216-e230. [CrossRef]

58. Lazzaro, B.P.; Zasloff, M.; Rolff, J. Antimicrobial peptides: Application informed by evolution. Science 2020, 368 , eaau5480. [CrossRef]

59. Fantner, G.E.; Barbero, R.J.; Gray, D.S.; Belcher, A.M. Kinetics of antimicrobial peptide activity measured on individual bacterial cells using high-speed atomic force microscopy. Nat. Nanotechnol. 2010, 5, 280-285. [CrossRef]

60. Yu, G.; Baeder, D.Y.; Regoes, R.R.; Rolff, J. Predicting drug resistance evolution: Insights from antimicrobial peptides and antibiotics. Proc. Biol. Sci. 2018, 285, 20172687. [CrossRef]

61. Wang, C.; Hong, T.; Cui, P.; Wang, J.; Xia, J. Antimicrobial peptides towards clinical application: Delivery and formulation. Adv. Drug Deliv. Rev. 2021, 175, 113818. [CrossRef]

62. Pan, C.Y.; Chen, J.Y.; Cheng, Y.S.; Chen, C.Y.; Ni, I.H.; Sheen, J.F.; Pan, Y.L.; Kuo, C.M. Gene expression and localization of the epinecidin-1 antimicrobial peptide in the grouper (Epinephelus coioides), and its role in protecting fish against pathogenic infection. DNA Cell Biol. 2007, 26, 403-413. [CrossRef] [PubMed]

63. Pan, C.Y.; Chen, J.C.; Sheen, J.F.; Lin, T.L.; Chen, J.Y. Epinecidin-1 has immunomodulatory effects, facilitating its therapeutic use in a mouse model of Pseudomonas aeruginosa sepsis. Antimicrob. Agents Chemother. 2014, 58, 4264-4274. [CrossRef] [PubMed]

64. Subramanian, S.; Ross, N.W.; MacKinnon, S.L. Myxinidin, a novel antimicrobial peptide from the epidermal mucus of hagfish, Myxine glutinosa L. Mar. Biotechnol. 2009, 11, 748-757. [CrossRef] [PubMed]

65. Cantisani, M.; Finamore, E.; Mignogna, E.; Falanga, A.; Nicoletti, G.F.; Pedone, C.; Morelli, G.; Leone, M.; Galdiero, M.; Galdiero, S. Structural insights into and activity analysis of the antimicrobial peptide myxinidin. Antimicrob. Agents Chemother. 2014, 58, 5280-5290. [CrossRef] [PubMed]

66. Seo, J.K.; Lee, M.J.; Jung, H.G.; Go, H.J.; Kim, Y.J.; Park, N.G. Antimicrobial function of SHbetaAP, a novel hemoglobin beta chain-related antimicrobial peptide, isolated from the liver of skipjack tuna, Katsuwonus pelamis. Fish Shellfish Immunol. 2014, 37, 173-183. [CrossRef] [PubMed]

67. Chen, B.; Fan, D.Q.; Zhu, K.X.; Shan, Z.G.; Chen, F.Y.; Hou, L.; Cai, L.; Wang, K.J. Mechanism study on a new antimicrobial peptide Sphistin derived from the N-terminus of crab histone H2A identified in haemolymphs of Scylla paramamosain. Fish Shellfish Immunol. 2015, 47, 833-846. [CrossRef] [PubMed] 
68. Ma, X.W.; Hou, L.; Chen, B.; Fan, D.Q.; Chen, Y.C.; Yang, Y.; Wang, K.J. A truncated Sph12-38 with potent antimicrobial activity showing resistance against bacterial challenge in Oryzias melastigma. Fish Shellfish Immunol. 2017, 67, 561-570. [CrossRef]

69. Liu, J.; Chen, F.; Wang, X.; Peng, H.; Zhang, H.; Wang, K.J. The synergistic effect of mud crab antimicrobial peptides Sphistin and Sph12-38 With antibiotics azithromycin and rifampicin enhances bactericidal activity against Pseudomonas aeruginosa. Front. Cell. Infect. Microbiol. 2020, 10, 572849. [CrossRef] [PubMed]

70. Kawano, K.; Yoneya, T.; Miyata, T.; Yoshikawa, K.; Tokunaga, F.; Terada, Y.; Iwanaga, S. Antimicrobial peptide, tachyplesin I, isolated from hemocytes of the horseshoe crab (Tachypleus tridentatus). NMR determination of the beta-sheet structure. J. Biol. Chem. 1990, 265, 15365-15367. [CrossRef]

71. Yu, R.; Wang, J.; So, L.Y.; Harvey, P.J.; Shi, J.; Liang, J.; Dou, Q.; Li, X.; Yan, X.; Huang, Y.H.; et al. Enhanced activity against multidrug-resistant bacteria through coapplication of an analogue of Tachyplesin I and an inhibitor of the QseC/B signaling pathway. J. Med. Chem. 2020, 63, 3475-3484. [CrossRef] [PubMed]

72. Tareq, F.S.; Lee, M.A.; Lee, H.S.; Lee, Y.J.; Lee, J.S.; Hasan, C.M.; Islam, M.T.; Shin, H.J. Gageotetrins A-C, noncytotoxic antimicrobial linear lipopeptides from a marine bacterium Bacillus subtilis. Org. Lett. 2014, 16, 928-931. [CrossRef] [PubMed]

73. Raju, R.; Khalil, Z.G.; Piggott, A.M.; Blumenthal, A.; Gardiner, D.L.; Skinner-Adams, T.S.; Capon, R.J. Mollemycin A: An antimalarial and antibacterial glyco-hexadepsipeptide-polyketide from an Australian marine-derived Streptomyces sp. (CMBM0244). Org. Lett. 2014, 16, 1716-1719. [CrossRef] [PubMed]

74. Song, Q.; Li, X.-M.; Hu, X.-Y.; Li, X.; Chi, L.-P.; Li, H.-L.; Wang, B.-G. Antibacterial metabolites from Ascidian-derived fungus Aspergillus clavatus AS-107. Phytochem. Lett. 2019, 34, 30-34. [CrossRef]

75. Auckloo, B.N.; Pan, C.; Akhter, N.; Wu, B.; Wu, X.; He, S. Stress-driven discovery of novel cryptic antibiotics from a marine fungus Penicillium sp. BB1122. Front. Microbiol. 2017, 8, 1450. [CrossRef]

76. Orfali, R.; Perveen, S.; Al-Taweel, A.; Ahmed, A.F.; Majrashi, N.; Alluhay, K.; Khan, A.; Luciano, P.; Taglialatela-Scafati, O. Penipyranicins A-C: Antibacterial methylpyran polyketides from a hydrothermal spring sediment Penicillium sp. J. Nat. Prod. 2020, 83, 3591-3597. [CrossRef]

77. Wyche, T.P.; Alvarenga, R.F.R.; Piotrowski, J.S.; Duster, M.N.; Warrack, S.R.; Cornilescu, G.; De Wolfe, T.J.; Hou, Y.; Braun, D.R.; Ellis, G.A.; et al. Chemical genomics, structure elucidation, and in vivo studies of the marine-derived anticlostridial ecteinamycin. ACS Chem. Biol. 2017, 12, 2287-2295. [CrossRef] [PubMed]

78. Sharma, A.; Biharee, A.; Kumar, A.; Jaitak, V. Antimicrobial terpenoids as a potential substitute in overcoming antimicrobial resistance. Curr. Drug Targets 2020, 21, 1476-1494. [CrossRef] [PubMed]

79. Chi, L.P.; Li, X.M.; Wan, Y.P.; Li, X.; Wang, B.G. Ophiobolin sesterterpenoids and farnesylated phthalide derivatives from the deep sea cold-seep-derived fungus Aspergillus insuetus SD-512. J. Nat. Prod. 2020, 83, 3652-3660. [CrossRef] [PubMed]

80. Sullivan, G.J.; Delgado, N.N.; Maharjan, R.; Cain, A.K. How antibiotics work together: Molecular mechanisms behind combination therapy. Curr. Opin. Microbiol. 2020, 57, 31-40. [CrossRef] [PubMed]

81. Richter, M.F.; Drown, B.S.; Riley, A.P.; Garcia, A.; Shirai, T.; Svec, R.L.; Hergenrother, P.J. Predictive compound accumulation rules yield a broad-spectrum antibiotic. Nature 2017, 545, 299-304. [CrossRef] [PubMed]

82. Douafer, H.; Andrieu, V.; Phanstiel, O.t.; Brunel, J.M. Antibiotic adjuvants: Make antibiotics great again! J. Med. Chem. 2019, 62, 8665-8681. [CrossRef] [PubMed]

83. Du, Y.; Sun, J.; Gong, Q.; Wang, Y.; Fu, P.; Zhu, W. New alpha-pyridones with quorum-sensing inhibitory activity from diversityenhanced extracts of a Streptomyces sp. derived from marine algae. J. Agric. Food Chem. 2018, 66, 1807-1812. [CrossRef] [PubMed]

84. Zhou, J.W.; Luo, H.Z.; Jiang, H.; Jian, T.K.; Chen, Z.Q.; Jia, A.Q. Hordenine: A novel quorum sensing inhibitor and antibiofilm agent against Pseudomonas aeruginosa. J. Agric. Food Chem. 2018, 66, 1620-1628. [CrossRef] [PubMed] 